\title{
高強度材料を用いたコンクリート充てん鋼管柱の曲げせん断性状
}

\section{SHEAR-FLEXURAL BEHAVIOR OF CONCRETE FILLED STEEL TUBULAR BEAM-COLUMNS USING HIGH STRENGTH MATERIALS}

\author{
藤本利 昭*1, 向井昭義*2, 西山 功*3, 稲井栄一*4, 甲斐 誠*5 \\ 時野谷 浩良*6, 馬塲 武 志*7, 福 元 敏之*8, 森 浩二*9 \\ 崎野健治*10, 森野捷輔*11 \\ Toshiaki FUJIMOTO, Akiyoshi MUKAI, Isao NISHIYAMA, \\ Eiichi INAI, Makoto KAI, Hiroyoshi TOKINOYA, \\ Takeshi BABA, Toshiyuki FUKUMOTO, Koji MORI, \\ Kenji SAKINO and Shosuke MORINO
}

\begin{abstract}
Recently, higher strength materials both for structural steel and concrete are frequently used for building structures. In this study, the effects of the material strengths on the beam-column behavior of concrete filled steel tube are experimentally studied. The selected test parameters are steel tube shapes (circular or square), material strength of structural steel and concrete, width (diameter)-to-thickness ratio of steel tube, axial load ratios (constant or variable), and loading directions (uniaxial or biaxial). The test results can be generally summarized that higher strength steel tube brought better overall behavior of beam-columns, while higher strength concrete brought adverse effect on the behavior.
\end{abstract}

Keyword : concrete filled steel tube, high strength material, beam-column test, variable axial load, biaxial bending コンクリート充てん鋼管, 高強度材料, 柱の曲げせん断実験, 変動軸力; 2 軸曲げ

\section{1. はじめに}

近年、コンクリート充てん鋼管(以下 CFT とする)構造に関する研 究が盛んに行われ、その優れた性能が注目されている。

一般に CFT 柱の構造性能を把握するために、実構造物の柱を模擬 した実験として、部材に一定の軸圧縮力を載荷し、繰り返しの水平 力を加えることで曲げモーメントとせん断力を作用させる加力形式 による実験、いわゆる柱の曲げせん断実験が行われており、現在ま でに数 100 体に及ぶ実験データが蓄積されている。それらの研究に よれば CFT 柱は充てんコンクリートの存在により鋼管の局部座屈が 拘束され、逆に鋼管の存在により充てんコンクリートは拘束を受け、 曲げ酎力および変形性能が向上することが報告されている 1)。しか しながら、近年の高強度材料の普及に伴い、色々な材料強度の組み 合わせが可能となった今日では、高強度材料を含めた材料強度の組 み合わせによる CFT 柱の構造性能の把握が必要となってきている。

一方、阪神・淡路大震災では、構造物の様々な破壊現象が発生し、 実際の地震入力に対して更なる検討が必要であることが表面化して
おり、特に地震時の軸力変動による影響および地震力の入力方向の 影響に関しては不明な点が多い。

実構造物においては、地震時に作用する転倒モーメントの影響に より軸力変動が生じ、場合によっては圧縮軸力のみならず、引張軸 力が作用する場合もある。しかしながら CFT 柱に関しては、軸力を 変動させた実験、ましてゃ引張軸力の作用する柱の曲げせん断挙動 に関する研究は皆無であり、その性能は明らかにされていない。

地震力の入力方向に関しても、2 軸曲げに関する研究は、CFT 角 形柱に関しては解析的研究として文献 2)があるものの、実験研究は ほとんど行われていないのが現状である。

そこで本研究は、今日においても明らかにされていないCFT 柱の 挙動に着目し、材料強度の組み合わせが構造性能へ与える影響、一 定軸力を受ける柱と変動軸力を受ける柱の構造性能の差異、および 水平力の載荷方向の違いが構造性能に与える影響を比較検討するた め、CFT 柱の曲げせん断実験を実施し、軸方向力と繰り返し水平力 を受ける CFT 柱の挙動を把握することを目的とした。

\footnotetext{
本論文は，日本建築学会大会学術講演梗概集（1996）「ハイブリッド構造に関する日米共同構造実験研究（CFT9〜16)」に加簕，修正したものである。

*1 安藤建設侏技術研究所 研究員・I修

*2 建設省建築研究所 耐風研究室長・王修

*3 建設省建築研究所 住宅建設研究室長.工博

*4 ハザマ技術研究所 主任研究皟・博士(工学)

*5 株松村組術研究所

*6 林組技術研究所 研究員・工修

*7 (侏)大本組建筑本部

*8 鹿島建設(侏技術研究所主任研究員. 工员博

*9 侏淺沼組技術研究所

*10 九州大学工学部建築学科 教授. 工博

*11 三重大学工学部建築学科 教授. 工博

Research Engineer, Research Center, Ando Corporation, M. Eng

Head, Building Research Institute, Ministry of Construction, M. Eng.

Head, Building Research Institute, Ministry of Construction, Dr. Eng.

Senior Research Engineer, Technical Research Institute, Hazama Corporation, Dr. Eng.

Technical Research Institute, Matsumura Gumi Corporation

Technical Research Institute of Obayashi Corporation, M. Eng

Ohmoto Gumi Co., Ltd.

Senior Research Engineer, Kajima Technical Research Institute, Dr. Eng.

Technical Research Institute, Asanuma Corporation

Prof., Department of Architecture, Faculty of Engineering, Kyushu University, Dr. Eng.

Prof., Department of Architecture, Faculty of Engineering, Mie University, Dr. Eng.
} 


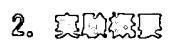

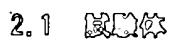

試験体の一覧を表-1 に示す。試験体は、铒面形状、鋼管の材料強 度、コンクリート強度、鋼管の幅厚比(径厚比)、軸力比および載荷 方向を実験変数とした円形断面試験体 13 体、正方形盺面を有する 角形断面 1 軸曲げ試験体 16 体、および 2 軸曲げ試験体 4 体の計 33 体である。

铜管強度は、400(SN400B), 590(SA440), 780(SHY685)MPa 級鋼の 3 種穎、コンクリート強度 Fc は 40, 90MPa の 2 種穎とした。また、 鈎管の蝠厚比(径厚比)は、日本建築センター「建築物の棈造規定」4)に より、材料の降伏強度を考慮した幅厚比により FA と FC クラスの 2 種穎とした。軸力は長期軸力を想定した一定軸力 $0.4 \mathrm{~N}_{\mathrm{o}}\left(\mathrm{N}_{\mathrm{o}}\right.$ : 軸圧縮耐 力) と変動軸力 $-0.3 \mathrm{~N}_{\mathrm{s}}\left(\mathrm{N}_{\mathrm{s}}:\right.$ 鋼管部分の軸圧縮耐力) $0.7 \mathrm{~N}_{0}$ の 2 種穎とし た。なお、2 軸曲げ試験体は軸力一定 $0.4 \mathrm{~N}_{\mathrm{o}}$ とし、加力方向(45 度、 22.5 度)および仏料強度を変化させた。

試験体形状を図-1に示す。試験体は試験部分の柱頭、柱脚部分の 上下に加力スタブを取り付けた形状である。試験部分の柱長さは柱 径Dの6倍(せん断スパン比は3)である。柱内部へのコンクリートの打

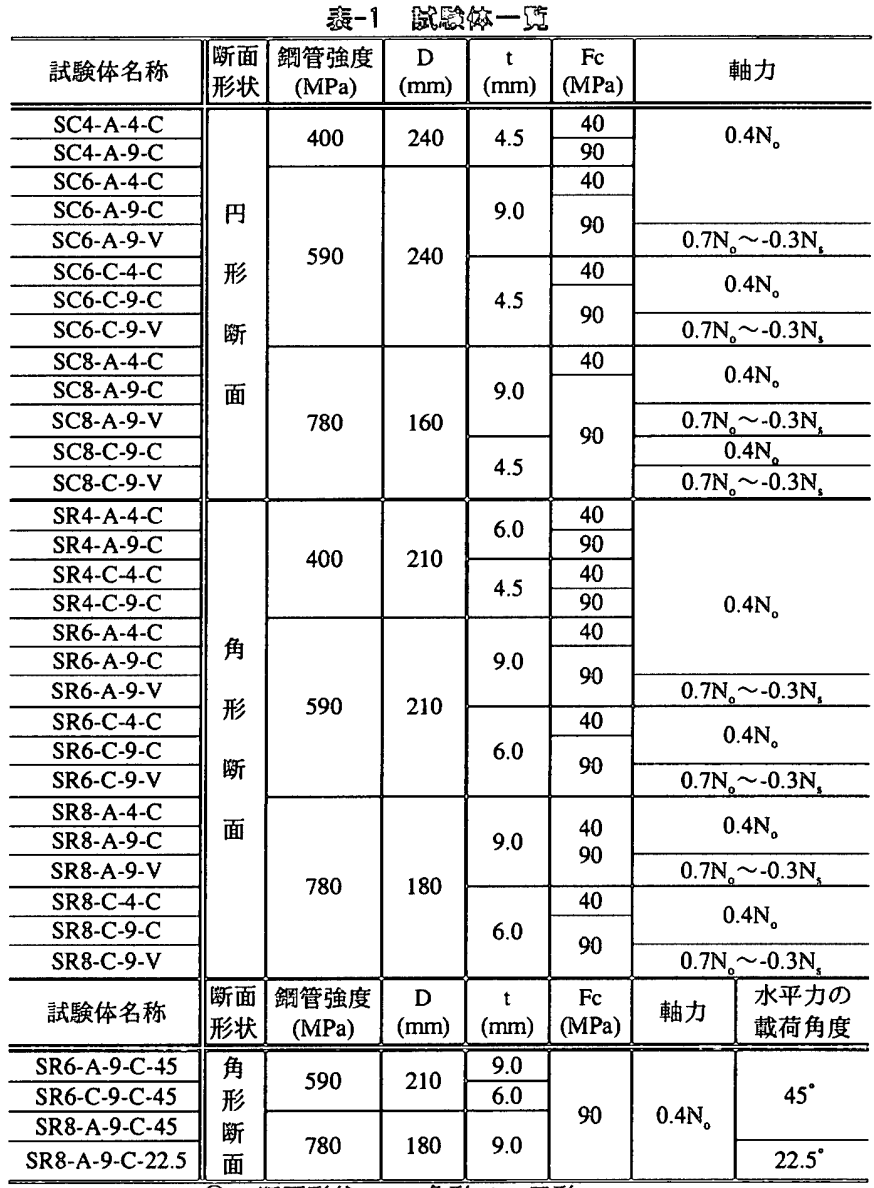

SR6-A-2-C-45 (1): 断面形状: R - 角形 C- 円形

(1)(2)(3)(4)(5)(6) (2): 鋼管強度 : 4-400MPa, 6-590MPa, 8-780MPa

(3) : 幅厚比：A-FAクラス, C-FCクラス

(4): コンクリート強度 : 4-40MPa, 9-90MPa

(5): 軸力比: C- 一定 $\left(0.4 \mathrm{~N}_{\mathrm{o}}\right), \mathrm{V}$-変動 $\left(0.7 \mathrm{~N}_{\mathrm{o}} \sim-0.3 \mathrm{~N}_{\mathrm{s}}\right)$

(6) : 加力方向 : $45-45^{\circ}, 22.5-22.5^{\circ}$

軸力の符号 : 压蹜を正、引張を負とする

$D, t:$ 断面せい(径)および龬管板厚

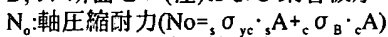

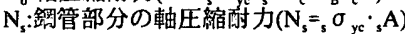

$\sigma, \mathrm{A}$ : 鎘管の厌解降伏強度および断面皘

$\sigma_{\mathrm{B}} 、 \mathrm{~A}$ ：コンクリートの圧縮強度および断面稳
設は繸打ちとし、上スタブの上面に設けた孔から行った。

CFT 柱鋼管の製作は冷間曲げ加工で行い、円形鋼管は 1 シームと し、鋼板をほほ円形と見なせる程度の多角形に曲げ加工して継ぎ目 を溶接した。角形鋼管は 2 シームとし、鋼板を 2 つのコ形に曲げ加 エして継ぎ目を溶接した。角形鋼管のコーナ一部外側の曲率半径 $\mathrm{R}$ は板厚の 3 倍とした。なお、鋼管の応力除去焼鈍は行っていない。

加力スタブは厚さ $22 \mathrm{~mm}$ の冷間成形の角形鋼管に剛性を高めるた めにコンクリートを充てんした。なお、柱の鋼管は加力スタブ内を 貫通し、柱鋼管と加力スタブ鋼管は溶接されている。
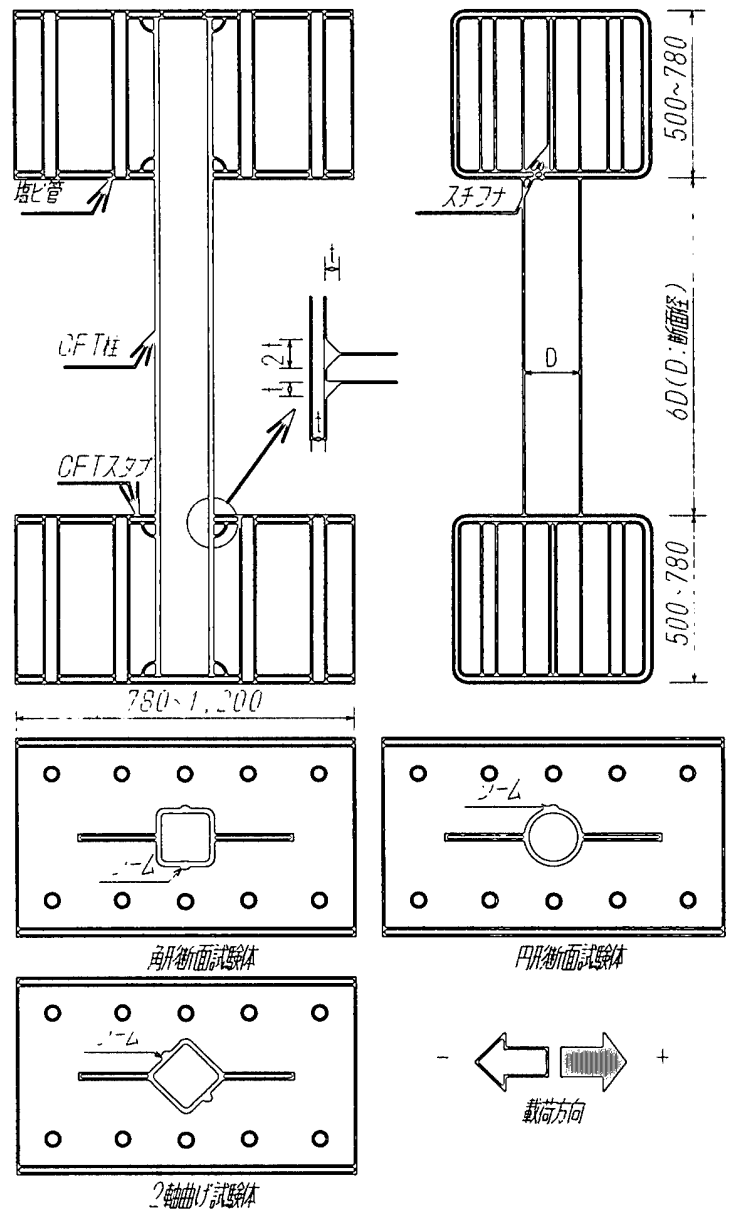

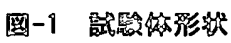

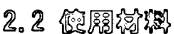

使用した鋼管およびコンクリートの機械的性質を、コンクリート については表-2に、鋼材については表-3に示す。

コンクリート強度用供試体は、 $\phi 100 \times 200$ とし、圧縮試験用供試 体は軽量型杂、割裂試験用供試体は鋳鋼製型染により製作し、封か ん養生とした。試験は端面研磨処理後に実施した。

鋼材引張試験片は冷間加工する前の鋼板より切り出した 1 号 $\mathrm{A}$ 試 験片を用いた。鋼管の圧縮試験は、試験体と同一断面の鋼管につい て行った。ただし、角形鋼管で局部座屈により降伏耐力が確認でき

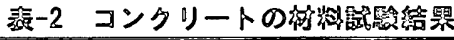

\begin{tabular}{c|c|c|c|c}
\hline & $\begin{array}{c}\text { 压縮強度 } \\
\sigma^{\sigma_{B}} \\
(\mathrm{MPa})\end{array}$ & $\begin{array}{c}\text { ヤング保数 } \\
\begin{array}{c}\mathrm{E} \\
(\mathrm{GPa})\end{array}\end{array}$ & $\begin{array}{c}\text { ポアソン比 } \\
\mathcal{V}\end{array}$ & $\begin{array}{c}\text { 割裂強度 } \\
{ }^{\sigma_{\mathrm{T}}} \\
(\mathrm{MPa})\end{array}$ \\
\hline \hline $40 \mathrm{MPa}$ & $35.5^{-} 42.4$ & $31.3^{-} 33.8$ & $0.18^{-} 0.23$ & $3.12^{-} 3.26$ \\
\hline $90 \mathrm{MPa}$ & $84.5^{-} 94.5$ & $36.2^{-} 38.6$ & $0.21^{-} 0.24$ & $4.85^{-} 5.01$ \\
\hline
\end{tabular}


ない場合は、幅厚比の小さい試験体の試験結果を用いた(文献 5 参 照)。なお、降伏強度 $\left(\sigma_{\mathrm{s}} \sigma_{\mathrm{y}}\right.$ および $\left.\sigma_{\mathrm{s}} \sigma_{\mathrm{yc}}\right)$ は $0.2 \%$ オフセット耐力である。

表-3 鋼材の材料試験結果

\begin{tabular}{|c|c|c|c|c|c|c|c|}
\hline & \multirow[b]{2}{*}{$\begin{array}{c}\text { 板厚 } \\
\mathrm{t} \\
(\mathrm{mm})\end{array}$} & \multicolumn{4}{|c|}{ 素材の引張試験結果 } & \multirow{2}{*}{$\begin{array}{c}\text { 鋼管の圧縮 } \\
\text { 降伏強度 } \\
{ }^{\circ} \sigma_{\mathrm{yc}} \\
(\mathrm{MPa})\end{array}$} \\
\hline & & & $\begin{array}{c}\text { 降伏強度 } \\
{ }^{s} \sigma_{y} \\
(\mathrm{MPa})\end{array}$ & $\begin{array}{c}\text { 引張強度 } \\
{ }_{s} \sigma_{1} \\
(\mathrm{MPa})\end{array}$ & $\begin{array}{c}\text { 降伏比 } \\
\text { YR }\end{array}$ & $\begin{array}{c}\text { 破断伸び } \\
\varepsilon \\
(\%)\end{array}$ & \\
\hline \multirow{5}{*}{$\begin{array}{l}\text { 円 } \\
\text { 形 } \\
\text { 鋼 } \\
\text { 管 }\end{array}$} & $400 \mathrm{MPa}$ & 4.71 & 284 & 449 & 0.633 & 24.7 & 338 \\
\hline & \multirow{2}{*}{$590 \mathrm{MPa}$} & 4.52 & 504 & 662 & 0.761 & 23.6 & 530 \\
\hline & & 9.00 & 482 & 618 & 0.780 & 24.0 & 508 \\
\hline & \multirow{2}{*}{$780 \mathrm{MPa}$} & 4.76 & 771 & 788 & 0.979 & 10.0 & 785 \\
\hline & & 9.12 & 820 & 833 & 0.984 & 11.7 & 806 \\
\hline \multirow{6}{*}{$\begin{array}{l}\text { 角 } \\
\text { 形 } \\
\text { 鋼 } \\
\text { 管 }\end{array}$} & \multirow{2}{*}{$400 \mathrm{MPa}$} & 4.50 & 276 & 412 & 0.669 & 29.0 & 326 \\
\hline & & 5.84 & 295 & 434 & 0.679 & 29.0 & 323 \\
\hline & \multirow{2}{*}{$590 \mathrm{MPa}$} & 5.95 & 540 & 669 & 0.808 & 12.9 & 609 \\
\hline & & 8.83 & 537 & 673 & 0.797 & 14.1 & 588 \\
\hline & \multirow{2}{*}{$780 \mathrm{MPa}$} & 6.66 & 824 & 851 & 0.968 & 11.0 & 805 \\
\hline & & 9.45 & 825 & 865 & 0.954 & 11.9 & 837 \\
\hline
\end{tabular}

\section{3 加カおよび計眮方法}

図-2に加力方法を示す。加力は、軸力を載荷しながら上下加力ス タブの平行度を保つと同時に上部スタブを下部スタブに対して水平 移動するようにせん断力を加える方法である。

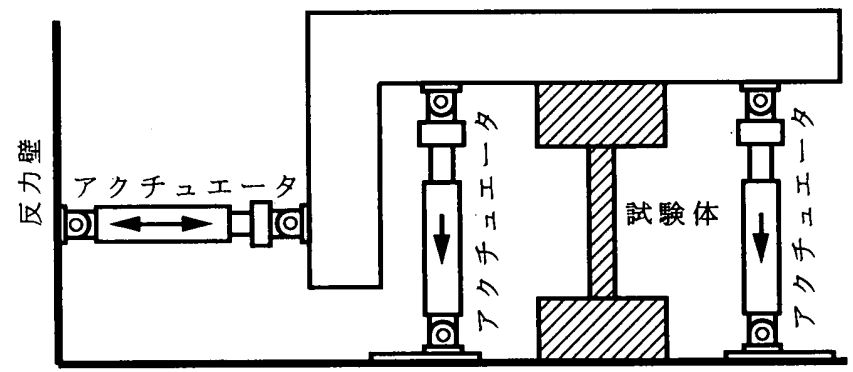

图-2 加力方法

載荷は正負繰り返し加力とし、所定の軸力を載荷後、せん断力を 図-3 に示寸載荷ルールに従い載荷した。最終サイクルは、せん断力 を一方向漸増載荷し、材端の曲げモーメントが最大曲げモーメント の $80 \%$ に低下することを確認するか、もしくは部材角が $6 \%$ に達す るまで継続することを原則とした。

また、変動軸力試験体の軸力載荷ルールは、図-4 に示すように、 圧縮軸力 $0.7 \mathrm{~N}_{\mathrm{o}}$ を正方向、引張軸力 $-0.3 \mathrm{~N}_{\mathrm{s}}$ を負方向とし、压縮側、引 張側でそれぞれ軸力を一定とした。軸力の切り替えは、せん断力が 0 の時に行い、この際のP P $\delta$ 効果による部材角の変動は許容した。

計测は、変位について、水平変位、材軸方向変位および柱頭、柱

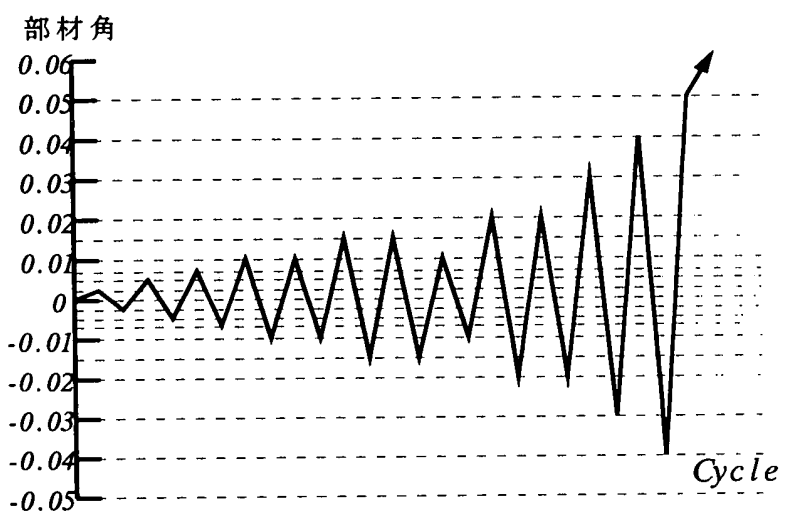

図-3 載荷ルール
脚の局部変位を測定した。また、ひずみは鋼管表面に貼付した塑性 2 軸および 3 軸ひずみゲージにより鋼管各部のひずみを測定した。

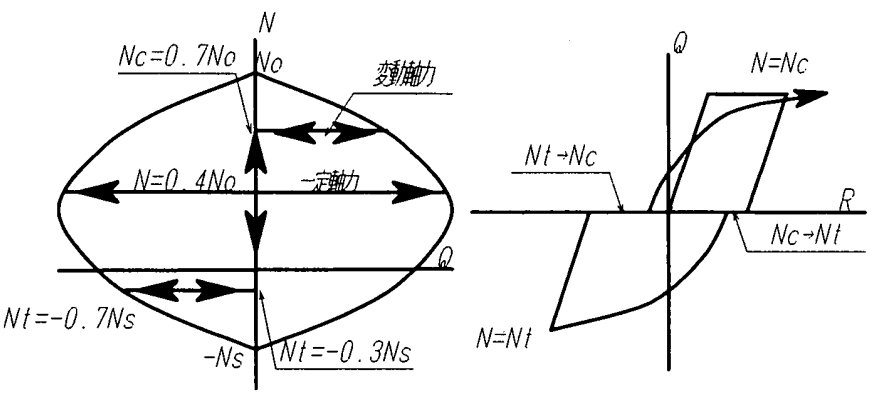

図-4＼cjkstart変動朝力試験体の載荷ルール

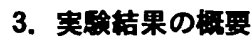

実験結果の一覧を表-4 に示す。ここで、計算曲げ耐力 ${ }_{\mathrm{c}} \mathrm{M}_{\mathrm{u}}$ は日本 建築学会 SRC 規準 ${ }^{6}$ による一般化累加式により、コンクリート強度 の低減係数 ${ }_{\mathrm{c}} \gamma_{\mathrm{u}}=1.0$ として求めた值である。なお、鋼管の降伏強度 には鋼管の圧縮降伏強度を用いた。曲げ耐力実験値 $\mathrm{e}^{\mathrm{M}} \mathrm{M}_{\mathrm{u}}$ は軸力によ る付加曲げモーメントを考慮した材端モーメントである。

図-5(a) (c)に各試験体の曲げモーメントー部材角関係、軸方向ひ ずみ一部材角関係を示す。ここでの曲げモーメント M は、P- $\delta$ 効果 を考慮した值である。また部材角 $\mathrm{R}$ は水平変位 $\delta$ 。を、軸方向ひず み $\varepsilon$ は部材の軸方向変位 $\delta$ を部材長さ $\mathrm{L} て ゙$ 除した值である。

表-4 実験結果一覧

\begin{tabular}{|c|c|c|c|c|c|c|c|c|c|c|c|}
\hline 試験体 & \begin{tabular}{|c|}
$\mathrm{D}$ \\
$\mathrm{mm}$
\end{tabular} & $\begin{array}{c}\mathrm{t} \\
\mathrm{mm} \\
\end{array}$ & $D / t$ & $\alpha$ & \begin{tabular}{|l}
$s_{v e}$ \\
$\mathrm{MPa}$
\end{tabular} & $\begin{array}{l}c_{\mathrm{B}}^{\sigma_{\mathrm{B}}} \\
\mathrm{MPa}\end{array}$ & \begin{tabular}{|l}
$\mathrm{N}$ \\
$\mathrm{No}$ \\
\end{tabular} & $\begin{array}{c}\mathrm{N} \\
\mathrm{kN}\end{array}$ & \begin{tabular}{|c|}
$\mathrm{eMu}$ \\
$\mathrm{kN} \cdot \mathrm{m}$ \\
\end{tabular} & \begin{tabular}{|c|}
$\mathrm{cMu}$ \\
$\mathrm{kN} \cdot \mathrm{m}$ \\
\end{tabular} & $\frac{\mathrm{eMu}}{\mathrm{cMu}}$ \\
\hline SC4-A-4-C & 241 & \multirow{2}{*}{4.70} & \multirow{2}{*}{\begin{tabular}{|l|}
51.3 \\
50.6 \\
\end{tabular}} & \multirow{2}{*}{0.08} & \multirow{2}{*}{338} & 39.2 & 0.37 & 1034 & 173 & 128 & 1.35 \\
\hline SC4-A-9-C & 238 & & & & & 88.2 & \begin{tabular}{|l|}
0.38 \\
\end{tabular} & 1784 & 202 & 174 & 1.16 \\
\hline SC6-A-4-C & \multirow{4}{*}{241} & \multirow{4}{*}{9.00} & 26.7 & \multirow{4}{*}{$0.07 \mid$} & \multirow{4}{*}{508} & 35.5 & \multirow{2}{*}{0.38} & 1809 & 371 & 255 & 1.45 \\
\hline SC6-A-9-C & & & \begin{tabular}{|l|}
26.8 \\
\end{tabular} & & & 84.4 & & \multirow{2}{*}{\begin{tabular}{|l|l|}
2567 \\
4688
\end{tabular}} & 422 & 313 & 1.35 \\
\hline SC6-A-9-V & & & 267 & & & \multirow{2}{*}{91.7} & $0.67 \mid$ & & 274 & 223 & 1.23 \\
\hline & & & & & & & -0.28 & -947 & -323 & -234 & 1.38 \\
\hline SC6-C-4-C & 238 & \multirow{4}{*}{4.52} & 52.6 & \multirow{4}{*}{0.14} & \multirow{4}{*}{530} & 35.5 & 0.45 & 1462 & 220 & 151 & 1.45 \\
\hline SC6-C-9-C & 240 & & \begin{tabular}{|l|}
53.1 \\
\end{tabular} & & & 84.4 & 0.39 & 2086 & 254 & 218 & 1.16 \\
\hline & & & & & & & \begin{tabular}{|l|}
0.68 \\
\end{tabular} & 3874 & 153 & 168 & 0.91 \\
\hline SC6-C-9-V & |241 & & 53.2 & & & 91.7 & -0.27 & -491 & -185 & -132 & 1.40 \\
\hline SC8-A-4-C & & & & & & 35.5 & & 1612 & 245 & 153 & 1.60 \\
\hline SC8-A-9-C & & & & & & & 0.41 & 1988 & 261 & 175 & 1.49 \\
\hline $\mathrm{SC} 8-\mathrm{A}-9-\mathrm{V}$ & 161 & 9.12 & 17.7 & 0.07 & 806 & & \begin{tabular}{|l|}
0.71 \\
\end{tabular} & 3457 & 173 & 109 & 1.59 \\
\hline $\sec 8-A-2=t$ & & & & & & 93.9 & -0.30 & -1026 & -147 & -156 & 0.94 \\
\hline SC8-C-9-C & 160 & & 33.6 & & & & \begin{tabular}{|l|}
0.39 \\
\end{tabular} & 1347 & 151 & 112 & 1.35 \\
\hline SC8-C-9.V & & & & & & & \begin{tabular}{|l|}
0.69 \\
\end{tabular} & 2359 & 110 & 75 & 1.48 \\
\hline & 1309 & 4.76 & 33.4 & 0.12 & 785 & 93.9 & -0.29 & -513 & -82 & -84 & 0.97 \\
\hline SR4-A-4-C & & & & & & 39.2 & 0.40 & 1162 & 187 & 145 & 1.29 \\
\hline SR4 & 210 & 5.80 & 36.2 & 1.31 & & 88.2 & 0.39 & 1895 & 225 & 197 & 1.14 \\
\hline SR4-C-4-C & 210 & & \begin{tabular}{|l|}
46.7 \\
\end{tabular} & 1.71 & & 39.2 & & \begin{tabular}{|l|}
1021 \\
\end{tabular} & 151 & 128 & 1.18 \\
\hline SR4-C-9-C & 209 & 4.50 & 46.4 & 1.70 & 320 & 88.2 & 0.40 & 1791 & 202 & 177 & 1.14 \\
\hline SR6-A-4-C & $211+3$ & & & & & 39.3 & & 1959 & 373 & 306 & 1.22 \\
\hline SR6-A-9-C & 211 & & & 1.22 & & 88.3 & & 2649 & 402 & 363 & 1.11 \\
\hline SR6-A-9-V & 210 & 8.83 & 238 & 121 & 588 & 917 & 0.70 & 4880 & 259 & 243 & 1.07 \\
\hline & & & & & & & -0.29 & -1070 & -302 & -276 & 1.09 \\
\hline SR6. & 211 & & 35.5 & 1.82 & & 39.3 & & 1545 & 263 & 244 & 1.08 \\
\hline SR6-C-9-C & 210 & & 35.3 & 1.81 & & 93.7 & 0.20 & 2368 & 295 & 303 & 0.97 \\
\hline SR6-C-9-Y & & 5.95 & & & 609 & & \begin{tabular}{|l|}
0.69 \\
\end{tabular} & 4326 & 163 & 217 & 0.75 \\
\hline SR $6-C-9-V$ & 212 & & 30.6 & 1.82 & & 91.1 & \begin{tabular}{|l|}
-0.30 \\
\end{tabular} & -769 & -226 & -209 & 1.08 \\
\hline SR8-A-4-C & 178 & & & 1.19 & & 42.3 & 0.43 & 2576 & 345 & 275 & 1.25 \\
\hline SR8-A-9-C & 179 & & & 1.20 & & & \begin{tabular}{|l|}
0.42 \\
\end{tabular} & 3077 & 377 & 322 & 1.17 \\
\hline & & 9.45 & 18.9 & & 837 & & \begin{tabular}{|l|}
0.72 \\
\end{tabular} & 5294 & 217 & 182 & 1.19 \\
\hline SR8-A-9-V & $1 / 8$ & & & 1.19 & & 94.5 & \begin{tabular}{|l|}
-0.32 \\
\end{tabular} & -1569 & -280 & -278 & 1.01 \\
\hline SR8- & & & & & & 42.3 & \begin{tabular}{|l|}
0.42 \\
\end{tabular} & 2003 & 240 & 217 & 1.11 \\
\hline SR8-C-9-C & & & & 1.70 & & & \begin{tabular}{|l|}
0.41 \\
\end{tabular} & 2540 & 264 & 262 & 1.01 \\
\hline SR8-C-9-V & 180 & 6.66 & 27.0 & 1.71 & 805 & 945 & 0.71 & 4437] & 146 & 149 & 0.98 \\
\hline & & & & & & & -0.31 & 1142 & -210 & -202 & 1.04 \\
\hline SR6-A-9-C-45 & 210 & 8.83 & 23.8 & 1.21 & 588 & 88.3 & \begin{tabular}{|l|l|}
0.38 \\
\end{tabular} & 2644 & 374 & 343 & 1.09 \\
\hline SR6-C-9-C-45 & 211 & 5.95 & 35.5 & 1.82 & 609 & 88.3 & 0.39 & 2358 & 270 & 284 & 0.95 \\
\hline SR8-A-9-C-45 & 181 & & 19.2 & 1.21 & 837 & 91.7 & 0.40 & 2965 & 371 & 326 & 1.14 \\
\hline SR8-A-9-C-22.5 & 180 & & 19.0 & 1.20 & 837 & 84.4 & \begin{tabular}{|l|l|}
0.39 \\
\end{tabular} & 2782 & 390 & 324 & 1.20 \\
\hline
\end{tabular}



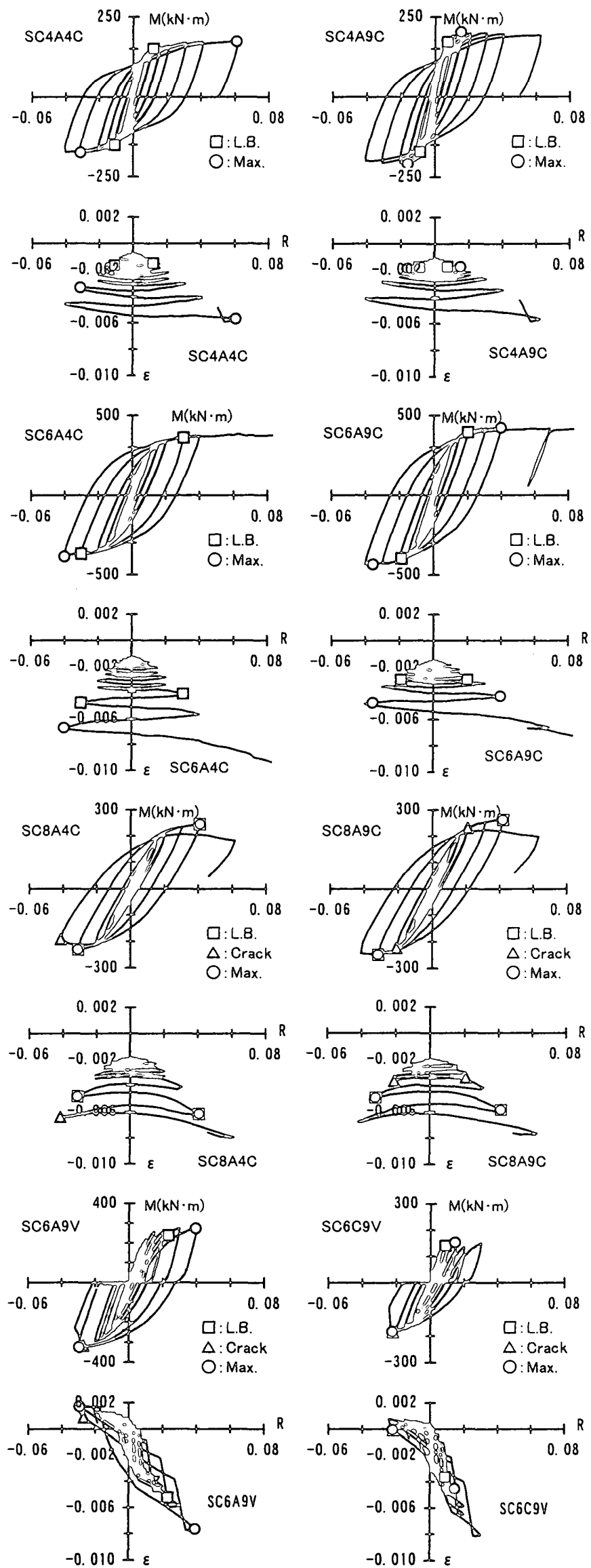

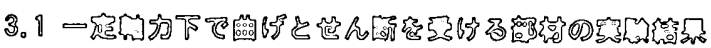

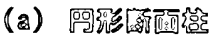

円形断面試験体は、圧縮フランジに局部座屈を確認した後曲げ耐 力を示した。変形能力は非常に大きく、曲け耐力時の部材角 $\mathrm{R}_{\max }$ は、 $400 \mathrm{MPa}$ 錻·Fc90MPa 試駼体(SC4A9C)は $1.5 \%$ でったが、他の試験 体は $3.0 \%$ を越えていた。曲げ耐力後の耐力劣化は、780MPa 鍊試験 体(SC8A4C, SC8A9C, SC8C9C)は、部材角士4\%の繰り返しサイクル 途中に材端部の引張フランジが破断し、耐力低下を示したものの、 他の試験体では激しい耐力劣化はほとんど認められず、非常に安定 した挙動を示した。590MPa 銅·Fc90MPa 試験体(SC6A9C, SC6C9C) は、最終サイクル時に村端部の引張フランジに部分的な破断が生じ たが、その影響による急激な耐力低下は認められなかった。各試験 体の曲け耐力は計算耐力の $1.16 \sim 1.60$ 倍を示した。
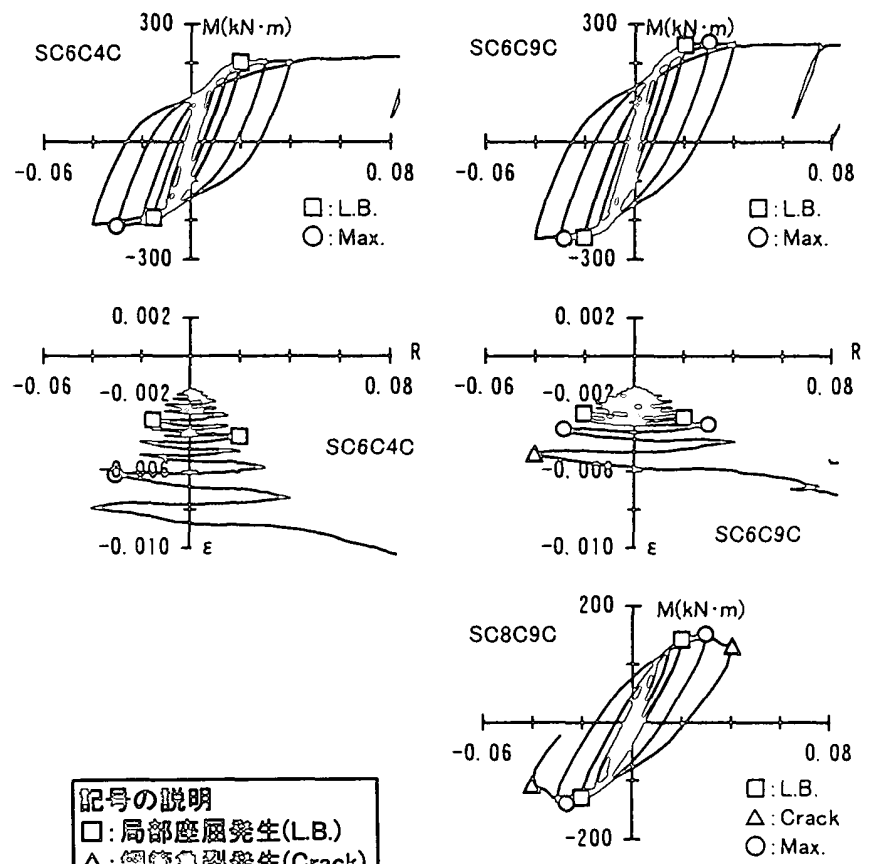

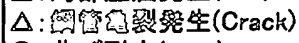
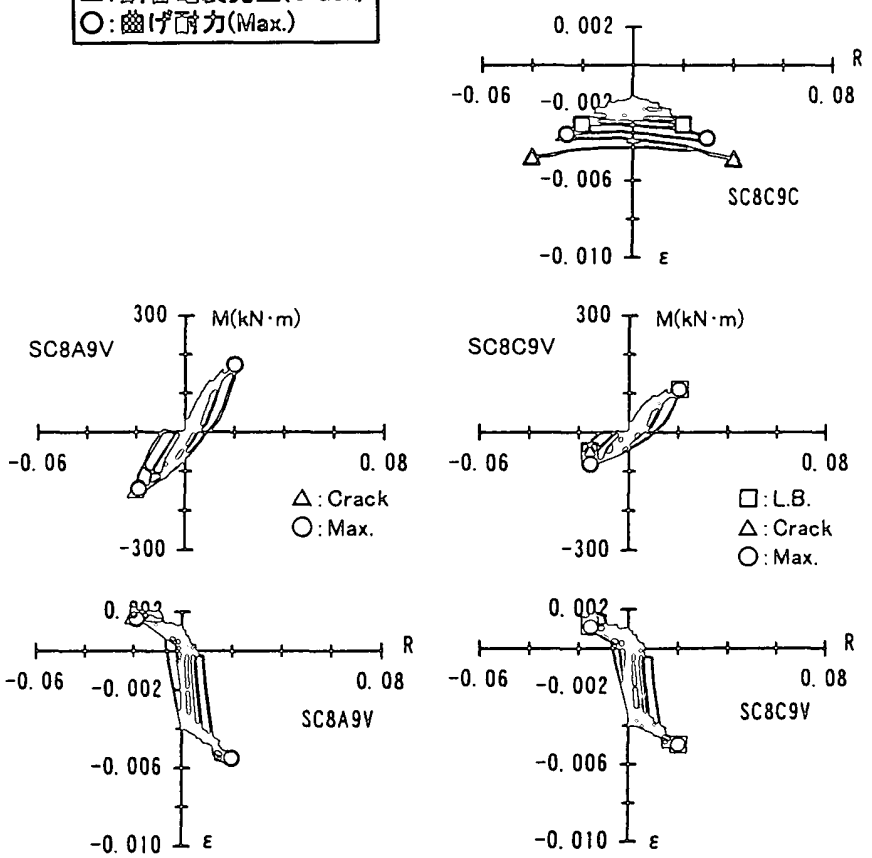

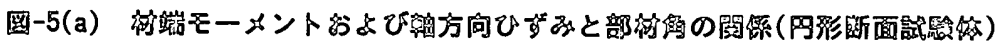



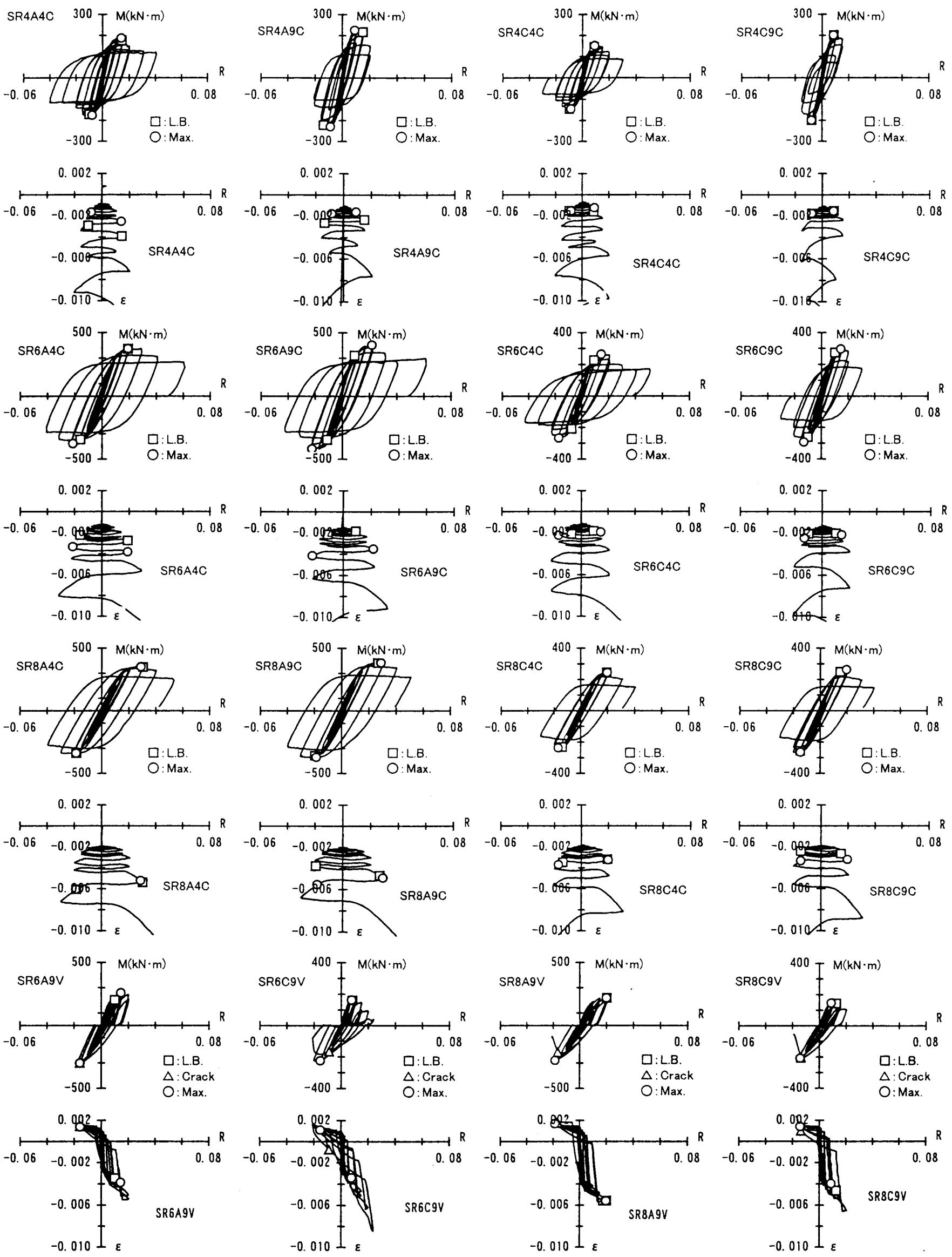

図-5(b) 材端モーメントおよび軸方向ひずみと部材角の閉係(角形断面試硂体) 

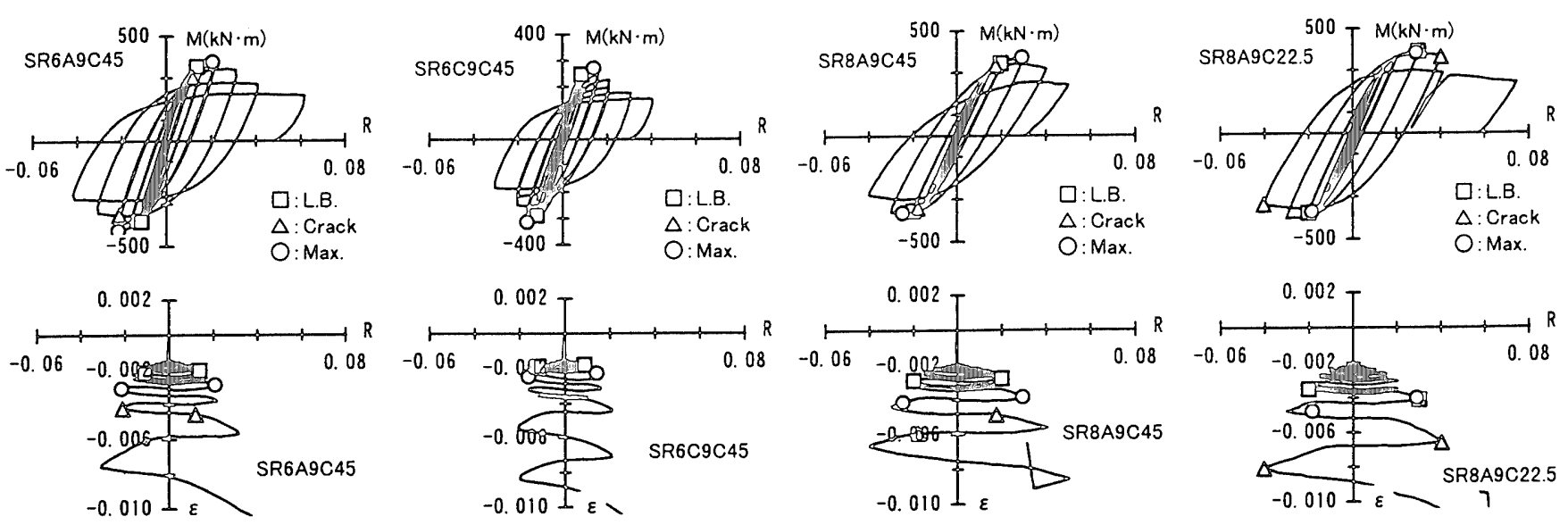

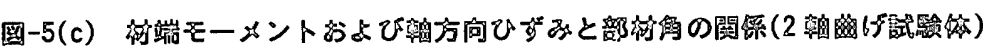

一方、軸方向ひずみと部材角の関係は、400, 590MPa 鋼試験体(SC4-, SC6-)では、下に凸の形状を示すのに対して、780MPa 鋼試験体(SC8-) では、上に凸の形状を示している。断面に曲げモーメントが作用す ると鋼管による力の負担が軸力から曲げモーメントに大きく変動す るため、鋼管の軸力負担割合が大きい780MPa 鋼試験体は、400MPa 銅試験体に比べ軸変形の増加が著しくなる。曲げモーメントを解除 すると、780MPa 鋼試験体は、コンクリートの塑性化による軸剛性 の少化に比べ、鋼管の軸力負担割合の回復が大きく、軸方向の変形 が戻る傾向を示すが、400MPa 鋼試験体は、鋼管の軸力負担割合が もともと小さいため、コンクリートの軸剛性の少化により、軸変形 が進展するものと考えられる。

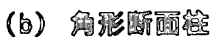

各試験体とも圧縮側フランジに局部座屈を確認した後、繰り返し 载荷の度に曲げ耐力が低下した。なお、鋼管の亀裂は発生しなかっ た。曲げ耐力は計算耐力に対して 0.95〜1.29であった。

曲げ耐力時の部材角 $\mathrm{R}_{\text {max }}$ は、 $400 \mathrm{MPa}$ 龬試験体(SR4-)が $1.0 \%$ 1.5\%、 $590 \mathrm{MPa}$ 鋼試験体(SR6-)が $1.5 \% \sim 2.0 \% 、 780 \mathrm{MPa}$ 鋼試験体(SR8-)が $2.0 \%$ ３.0\%であり、鋼管の材料強度が高い試験体ほど $\mathrm{R}_{\max }$ が大きく なる傾向が認められた。幅厚比の比較では、FAクラス試験体の $\mathrm{R}_{\max }$ が FC クラスに比ベ大きくなっている。また、他のパラメータが等 しくコンクリート強度が異なる場合には、Fc40MPa 試験体に比ベ、 Fc90MPa 試験体の $\mathrm{R}_{\max }$ が若干小さい值を示していた。特に、400MPa 龬·Fc90MPa 試験体(SR4A9C, SR4C9C)の $\mathrm{R}_{\max }$ は $1.0 \%$ 小さく、そ の後の耐力劣化も著しくなっている。

一方軸方向ひずみは、軸力載荷後の水平変形の繰り返しにより、 軸方向ひずみが累積し、局部座屈の発生後その累積割合が増加して いく。軸方向ひずみの累積は、冈形断面試験体に比べ顕著である。

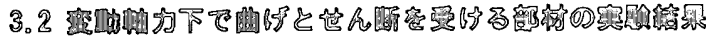

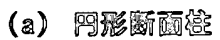

引張軸力下において、全試験体の鋼管に亀裂が発生した。780MPa 銅試験体(SC8A9V, SC8C9V)は引張軸力時の部材角-2\%の繰り返しサ イクル途中に材端部の引張フランジが破断し曲げ耐力が低下した。 $590 \mathrm{MPa}$ 銅試験体(SC6A9V, SC6C9V)においても、引張軸力時の部材 角-3〜4\%の繰り返しサイクル途中に材端部の引張フランジが破断し 曲げ耐力が低下した。圧縮軸力時には、590MPa鋼試験体では局部座 屈を確認した後に曲げ耐力を示したが、780MPa鋼試験体では局部座
屈は発生しなかった。圧縮軸力時の曲げ耐力は計算耐力に対して、 $590 \mathrm{MPa}$ 鎆·FCクラス試験体(SC6C9V)が0.91、他の3体は $1.23 \sim 1.59$ で あった。また引張軸力時の曲げ而力は、計算耐力に対して590MPa鎡 試験体は1.38〜1.40倍、780MPa鋼試験体は0.94，0.97であった。

圧縮軸力時の曲げ耐力時の部材角 $\mathrm{R}_{\text {max }}$ は、SC6A9Vが $4.0 \% 、 S C 6 C 9 \mathrm{~V}$ が1.5\%、SC8A9V、SR8C9Vが2.0\%で、引張軸力時のR $\mathrm{R}_{\text {max }}$ は、SC6A9V が3.0\%、SC6C9V、SC8A9Vが2.0\%、SC8C9Vが1.5\%で、同一断面の 一定軸力試験体に比べ小さい值であった。

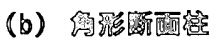

角形断面試験体は、圧縮軸力時に圧縮フランジに局部座屈が生じ た後、引張軸力時の部材角-2\%の絽り返しサイクル途中に材端部の 引張フランジが破断し、曲げ耐力が急激に低下した。圧縮軸力下に おいては、幅厚比 FC クラス試験体(SR6C9V, SR8C9V)の耐力低下が 大きく、圧縮軸力時の曲げ耐力は、計算耐力の $0.75,0.98$ と達して いない。また引張軸力時の曲げ耐力は 590MPa 鍓試験体(SR6A9V,

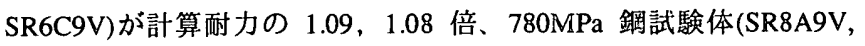
SR8C9V)は 1.01, 1.04 倍であった。

圧縮軸力時の曲げ耐力時の部材角 $\mathrm{R}_{\text {max }}$ は、SR6A9V が $1.5 \%$ 、 SR6C9V が 1.0\%、SR8A9V が 2.0\%、SR8C9V が $1.5 \%$ 、同一断面 の一定軸力試験体に比べ小さい值であった。一方引張軸力時の $\mathrm{R}_{\max }$ は、一定軸力試験体と同等であった。

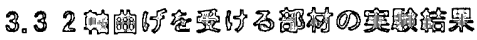

4 体とも圧縮側の平板部に局部座屈が生じた後、曲げ耐力を示し た。590MPa 鋼·FC クラス試験体(SR6C9C45)を除く 3 体は、曲げ耐 力後の絪り返し載荷中に引張側となる材端の鋼管フランジコーナー 部に亀裂が発生したが、激しい耐力低下は認められなかった。曲げ 耐力は計算耐力の $0.95 〜 1.20$ であった。

曲げ耐力時の部材角 $\mathrm{R}_{\text {max }}$ は、同一断面の 1 軸曲げ試験体の $\mathrm{R}_{\text {max }}$ とほほ対応しており、加力方向の違いによる差異は認められなかっ た。しかし、曲げ耐力後の耐力少化は、 1 軸曲げ試験体に比べ 2 軸 曲げ試験体が大きくなっていた。また、2 軸曲げの場合、22.5 に比 ベ $45^{\circ}$ の劣化割合が大きい傾向があった。

軸方向ひずみの累積は、1 軸曲げ試験体に比べ 2 軸曲げ試験体の 軸方向ひずみの累積が少なく、2 軸曲げ試験体では、22.5試験体に 比べ $45^{\circ}$ 試験体の軸方向ひずみの累積が少ない傾向を示した。 


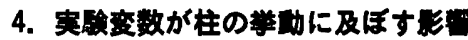

実験結果より、実験変数である断面形状、材料強度、軸力、加力 方向の違いによる CFT 柱の曲げ酎力および変形性能への影響を考 察する。なおここでは曲げ耐力時の部材角 $\mathrm{R}_{\max }$ をもって、試験体の 変形能力として評価した。

\section{1 断面形状 (网形・角形) の比度}

円形断面は角形断面に比べ鋼管の局部座屈および充てんコンクリ

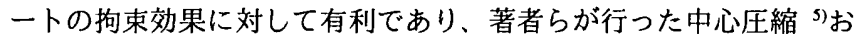
よび純曲げ実験 ${ }^{7,8)}$ と同様に、本実験においても変形性能、曲げ耐力 とも、角形断面に比べ円形断面が優れていた (図-6，図-7 参照)。

角形断面は、局部座屈の発生により軸方向ひずみが増加し、耐力 低下を示す。円形断面は、局部座屈発生後の耐力低下は僅かであり、 軸方向ひずみも急激な增加は認められない。その結果、円形断面で は断面圧縮縁の破壊が進行しないため断面引張縁に大きな変形能力 が必要になる。よって 590MPa, 780MPa 鋼を用いた円形断面試験体 では変形能力が他の試験体に比べ大きいため部材角 $4 \%$ \% た大変形時に、鋼管の破断が発生しているものと考えられる。

\section{2 村料強度の相み合わせの影变}

図-6に一定軸力試験体の最大耐力時の部材角 $\mathrm{R}_{\text {max }}$ と材料強度と の関係を示す。育形性能は鋼管の材料強度による影響が大きく、鋼 管の材料強度が高いほど変形能力が大きくなる。一方コンクリート 強度の違いによる傾向は、高強度が低強度に比べ変形能力が少って いる。しかしこのコンクリート強度による影響は、鋼管の材料強度 が低い場合には影著に現れるが、高強度の鋼管を用いた場合には、 僅かとなる。この結果は、文献 5)の中心圧縮実験結果と同様であり、 高強度コンクリートと低強度の鋼管の組み合わせになるほど変形性 能が劣る。コンクリートは高強度になるほど耐力後の劣化が著しい ため、その劣化を拘束するためには、鋼管による拘束力が必要とな り、その拘束力の向上には鋼管に高張力鋼を用いることが有効であ ることを示している。一方でこの傾向は、コンクリートによる鋼管 の局部座屈を抑制する効果は充てんコンクリートの存在自体が重要 であり、コンクリートの高強度化による局部座屈の抑制効果の向上 はあまり期待できないことを示している。

図-7に一定軸力試験体の材料強度と曲げ耐力比との関係を示す。 計算耐力に対する実験曲げ耐力の比(以下、曲げ耐力比とする)は、 円形断面試験体では鋼管が高強度になるほど大きく、角形断面では 鋼管強度の違いによる影響はほとんど認められない。一方で、コン クリート強度が異なる場合には、Fc40MPa 試験体に比べ Fc90MPa 試験体の曲げ耐力比が小さい傾向を示している。本実験のような加 力形式の場合、耐力上昇の要因としては、鋼管によるコンクリート の拘束効果、鋼管のひずみ硬化および加力治具等の拘束による影響 が考えられる。前出の文献 5),7),8)によれば、円形断面については鋼 管によるコンクリートの拘束効果による耐力上昇が認められるもの の、角形断面の場合拘束効果による耐力上昇は殆ど見込めないこと がわかっている。また加力治具の拘束による影響は、せん断スパン 比および軸力比を等しく設定している本実験では、各試験体にほほ 等しいレベルで含まれていると考えられる。ひずみ硬化による影響 は、曲げ酎力時の変形量が小さい角形断面試験体ではあまりなく、 曲げ耐力時の変形量が大きい円形断面試験体では、やや大きいと考 えられる。
円形断面について、コンクリートの拘束効果を考えてみると、コ ンファインドコンクリートの強度は、(1)式で示される。9)

$$
{ }_{\mathrm{c}} \sigma_{\mathrm{cB}}=\sigma_{\mathrm{p}}+2 \mathrm{t} \cdot \kappa \cdot{ }_{\mathrm{s}} \sigma_{\theta} /(\mathrm{D}-2 \mathrm{t})
$$

ここで、 ${ }_{\mathrm{c}} \sigma_{\mathrm{cB}}:$ コンファインドコンクリートの軸圧縮強度

$\sigma_{\mathrm{p}} \quad:$ プレーンコンクリートの軸圧縮強度

$\kappa \quad:$ 拘束係数

${ }_{s} \sigma_{\theta}:$ 鋼管の周方向応力

コンファインドコンクリートの強度上昇は鋼管の周方向応力によ り決まり、その周方向応力は鋼管の 1 軸降伏強度, $\sigma_{\mathrm{y}}$ に係数 $\alpha_{\mathrm{u}}$ を 乗じた $\alpha_{\mathrm{u}}{ }_{\mathrm{s}} \sigma_{\mathrm{y}}$ で表される。文献 9)によれば、係数 $\alpha_{\mathrm{u}}$ はほぼ一定と されており、円形断面では高張力鋼を用いることで拘束効果の上昇 が期待できるものと考えられる。

また、コンクリート強度の違いによる曲げ耐力比の差異は、高強 度コンクリートほど耐力劣化の拘束に鋼管の拘束力が必要となるこ とが影響しているものと考えられ、更に円形鋼管では(1)式によるコ ンクリートの強度上昇はプレーンコンクリートの強度とは無関係な ことから、高強度コンクリートの場合強度上昇の割合が小さくなる ためと考えられる。図-7には、(1)式を用いて算定した曲げ耐力に対 する実験值の比も併せて示してある。その結果材料強度の影響がほ ぼ説明できるものと考えられる。

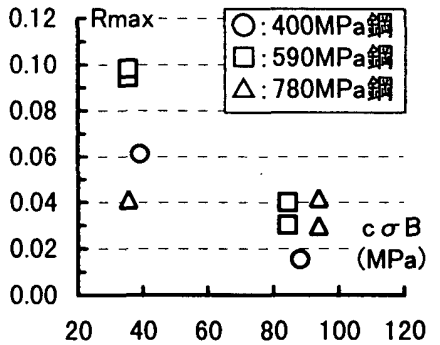

(a) 円形断面

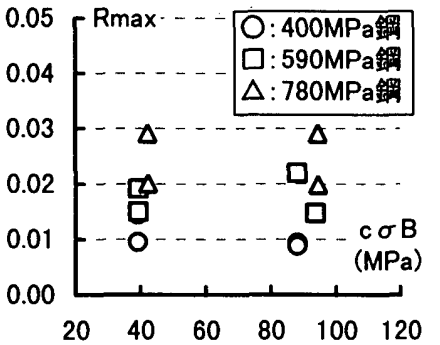

(b) 角形断面
图-6 変形性能の比較(材料強度の影響)

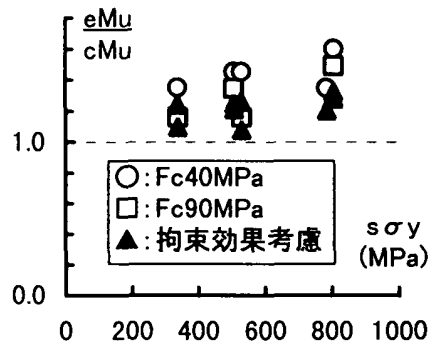

(a) 円形断面

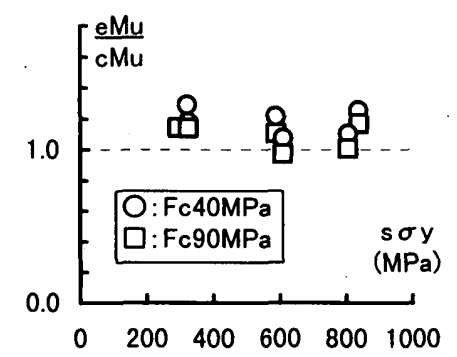

(b) 角形断面
图-7曲げ耐カ比の比較

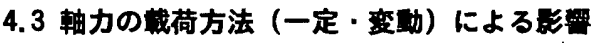

変動軸力の場合、圧縮軸力時には断面圧縮縁の破壊、引張軸力時 には断面引張縁の破壊により曲げ耐力および変形性能が決定した。

図-8に、柱材端断面の歪み分布の模式図を示す。一定軸力下で正 負繰り返しの曲げを受ける場合は、断面最外縁に同レベルの歪みが 生じ、ほほ均等に劣化すると考えられる。しかし変動軸力下におい ては、圧縮軸力時の引張縁(=引張軸力時の圧縮縁)は、ひずみの㚆動 が僅かとなるものの、圧縮軸力時の圧縮縁(=引張軸力時の引張縁)は、 大きな繰り返しひずみを受ける。 


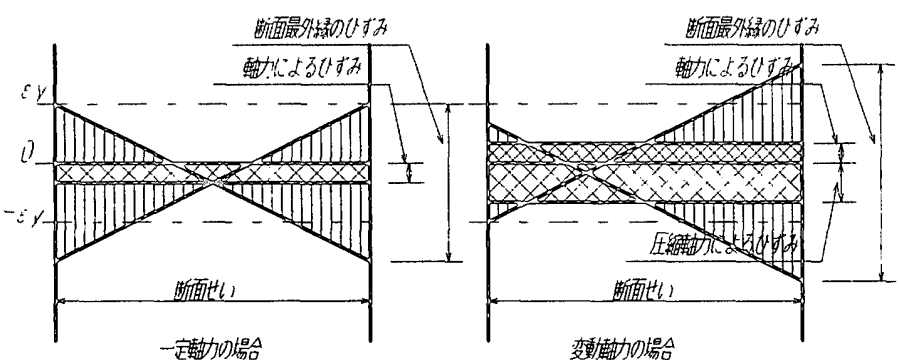

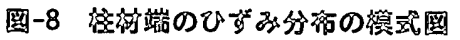

変動軸力試験体は、圧縮軸力時の変形性能は軸力比が一定軸力の 場合に比べ高いため、断面形状に関わらず一定軸力に比べ少る。曲 げ耐力に関しては、円形断面では、一定軸力の場合と同様に拘束効 果により耐力が上昇するが、幅厚比が大きい場合には局部座屈によ り耐力を発揮できない場合がある。角形断面では、曲げ耐力は局部 座屈による影響が大きいため、一定軸力試験体に比べ曲げ耐力比は 低くなり、特に幅厚比が大きくなるとその傾向が顕著になるものと 考えられる。

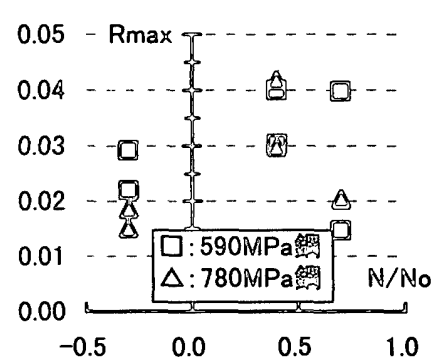

(a) 円郡断面

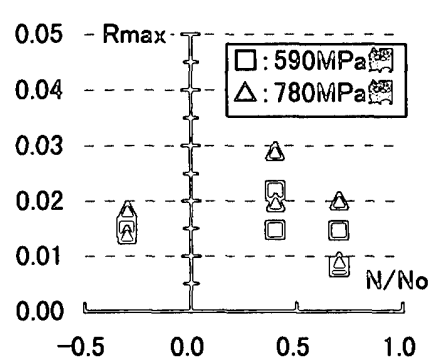

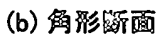

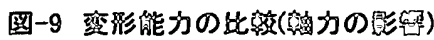

一方引張軸力時には、円形断面では鋼管が繰り返しによるひずみ の変動と同時に拘束効果による周方向ひずみを受けるため、変形性 能は一定軸力の場合に比べ劣る。しかし曲げ酎力は、その拘束効果 により耐力上昇するが、鋼管の伸び能力が小さい場合、計算耐力を 発揮する前に破断により曲げ耐力が決定することがある。角形断面 では、引張軸力㑡では局部座屈は発生せず、断面引張縁で変形性能 および曲げ耐力が決定するため、変形性能は一定軸力とほぼ同等で あり、曲け耐力に関しても計算耐力を発揮できたものと考えられる。

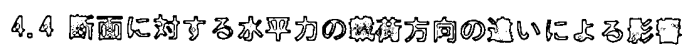

2 軸曲げを受ける柱においては、変形性能は 1 軸曲げの場合とほ ほ同等であった。しかしながら銅管の破断現象は 2 軸曲げ試験体の みのに発生した。2 軸曲げ試験体は、冷間成形により塑性加工を受 けた龬管コーナー部が断面の引張縁となり、応力状態が最も厳しく なることから発生したものと考えられる。ただし、2 軸曲げ試験体 は、鋼管の破断が発生したにもかかわらず、変形性能は 1 軸曲げ試 験体とほぼ同等であった。

2 軸曲げ試験体の曲げ耐力の局面を図-10 に示す。図中の実線は 一般化累加による耐力曲線である。2 軸曲げ試験体の曲げ耐力比は 同一畍面の 1 軸曲げ試験体と同等である。よって、角形断面柱の曲 げに対する変形性能および耐力は、加力方向が異なっても主軸方向 に対する性能と同等であるといえる。
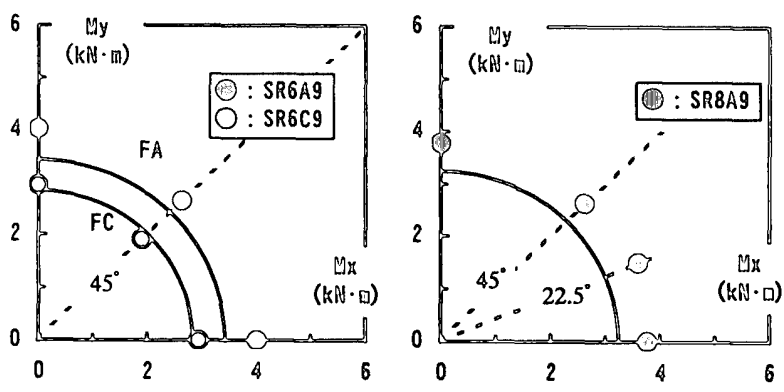

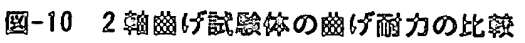

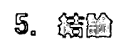

以上、CFT 柱の曲げせん断実験により、以下の結論を得た。

1) 変形性能は、高強度材料を用いた場合でも角形断面に比べ円形断 面試験体が優れている。

2) 角形断面CFT柱の曲げ耐力は材料強度の組み合わせに関わらず、 拘束効果による耐力上昇は認められない。円形断面 CFT 柱の曲 げ耐力は鋼管による拘束効果が認められ、特に高強度の鋼管を用 いた場合の拘束効果による耐力上昇が大きい。

3) 円形断面では鋼管の低強度化やコンクリートの高強度化が変形性 能の低下をもたらす傾向がある。

4) 変動軸力を受ける柱は、ひずみが断面の片側に累積するため、一 定軸力を受ける柱に比べ変形性能が劣る。

5) 2 軸曲げを受ける角形断面 CFT 柱は曲げ耐力、変形性能の両者 に関して、1 軸曲げを受ける場合と同等の性能を有する。

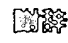

本研究は、ハイブリッド構造に関する日米共同構造実験研究(技術調整 委員会委員長:青山博之 東京大学名兴教授)の下で実施されたものであり、 コンクリート充てん龬管構造に関する研究は、CFT 分科会の下で行われ たものである。CFT 柱の曲げせん断実験は、建設省建築研究所と(社)建 築業協会とで分担して実施されたものであり、鋼管は(社)銅材俱楽部に て製作されたものである。ここに関係各位に謝意を表する。

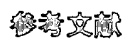

1）例えば、斉藤豊、他 : 充てん型銅管コンクリート柱に関する研究(その 1) （その 6)、日本建築学会大会梗概集、pp.1613〜1624、1989.10

2）川口淳、森野捷輔:軸力と 2 軸曲げを受ける銅·コンクリート複合断面 の終局強度相関曲線(その 1), 日本建築学会大会梗概集, 1992年 8月

3) 向井昭義、他:ハイブリッド構造に関する日米共同構造実験研究(CFT-9 〜16)コンクリート充てん銅管柱の曲げせん断性状 その 1〜8, 日本 建築学会大会梗概集, 1996 年 9 月

4）日本建築センター：建築物の構造規定，1994 年 9 月

5）藤本利昭、他：高強度材料を用いたコンクリート充てん銅管短柱の 軸压縮性状, 日本建築学会構造系論文集, 1997 年 8 月, No.498

6) 日本建築学会 : 鉄骨鉄筋コンクリート構造計算規準・同解説, 1987 年

7）畸野健治、松本勝蜜：ハイブリッド構造に関する日米共同構造実験 研究(CFT-7〜8) コンクリート充てん円形鋼管柱の純曲げ実験、日本 建築学会大会梗概集、pp.747 750、1995.8

8）藤本利昭、他：高強度材料を用いたコンクリート充てん角形銅管短 柱の偏心圧縮実験, 日本建築学会構造系論文集, 1997 年 11 月, No.501

9）日本建築学会 : コンクリート充填鋼管構造設計施工指針、1997年 10 月 